\title{
KULTURVÅRDENS PLATS I SAMHÄLLET
}

\author{
Sverker Janson
}

I flera olika sammanhang har här (i 'Kulturvård och sambällsbildning') framhållits, att det allmännas, sambällets, intressen har varit och är avgörande i äldre och nyare tid för utformningen av lagar och förordningar inom kulturvården. Sambället skall inte tillåta, att den enskilde fär fritt förfoga över vad som är landets urkunder, produkterna av gångna tiders arbete och sambällsbyggande, dvs. våra kulturminnen.

Detta gör, att kulturvården blir en samhällspolitisk fråga och inte, som nu är fallet, i stor utsträckning en antikvarisk fråga.

Kulturvården måste därför samordnas med samhällsutvecklingen, och detta medför många konsekvenser. Det krävs därvid först och främst en ständig anpassning till samhällsbildningen. När inte detta sker, blir kulturvården stillastående och övergår då i en fristående antikvarisk verksamhet, som sysslar till exempel med arkeologiska eller konsthistoriska undersökningar, värderingar och åtgärder, utan att dessa ställs i relation till den utveckling, som sker i samhället.

Inom kulturvården måste därför värderingar av objekt och miljöer av olika slag ske utifrån samhällssituationen. Detta kräver en ständig korrelation, en ständig anpassning till dagens samhällsbildning. Samhällets ständiga förändring, politiskt, ekonomiskt, socialt och kulturellt ställer ständigt nya krav på kulturvården.

Man kan säga, att samhällets mogna fruk- ter heter kulturminnen. Därför är motsättningen mellan gammalt och nytt i själva verket skenbar, då dagens samhällsprodukter $\mathrm{i}$ morgon är kulturminnen.

Men i verkligheten är emellertid tidsgränsen mycket starkt dominerande i all antikvarisk verksamhet. Ofta bildar den en oöverstiglig mur mot samtiden, och detta isolerar det antikvariska arbetet. Denna tidsgräns skjuts sedan ständigt framåt, och på så sätt införlivas visserligen nya kulturobjekt och kulturmiljöer undan för undan, men däremot alltid med en ny tidsbarriär emellan gången tid och nutid.

Detta förhindrar kanske mer än något annat en realistisk bedömning och värdering, när det gäller bevarande; detta oberoende om det är fråga om fornlämningar, byggnader, samhällen eller miljöer.

Det är därför också oerhört vanligt, att först när förslumning har skett, så omfattas objekten av intresse, och man försöker vidtaga räddningsåtgärder och restaureringar.

Tidsgränsen innebär vidare, att man inte 
92 når fram till en kontinuerlig vård av dagens produkter under ett längre skede. Utvecklingen måste så att säga ha fortskridit så långt, att dessa mer eller mindre har övergivits. Först då uppfattas de som kulturminnen och tillhör det antikvariska verksamhetsområdet.

Detta förlopp måste brytas. Kulturvården måste i stället vara en hushållning med våra egna samhällsprodukter, av våra kulturresurser. Miljövård blir då av naturliga skäl ett framträdande drag i arbetet.

Man talar ofta om, att man skall förhindra rovdrift av våra naturresurser. I själva verket är detta en allmänt godtagen inställning, som för de flesta är helt naturlig.

Här finns också gamla traditioner att falla tillbaka på. Redan i våra landskapslagar från 1200- och 1300-talet finner man bestämmelser om skogen. Bonden värnade under långa tider om de så kallade bärande träden som $\mathrm{ek}$, bok, hassel, vildapel och lind. Stränga bestämmelser utfärdade staten rörande ek och bok för att dessa naturtillgångar inte skulle förödas. Från 1900-talet har vi en modern skogslagstiftning i samma syfte. När det gäller vatten, mineraler, åkerjord och nu sist luften, så kan otaliga sådana exempel anges.

Det måste därför vara angeläget, att man också får och upprätthåller samma inställning, när det är fråga om våra kulturresurser. Vi måste motsätta oss all rovdrift av dem. Därför måste de bevaras, vårdas och brukas så, att de på samma sätt som våra naturresurser kan lämna en avkastning. Då blir kulturvård ett positivt inslag i samhällsbildningen och samhällsdebatten. Då skapas det också möjligheter för en aktiv kulturvård.

Detta kan man inte uppnå med en begränsad antikvarisk verksamhet, som ofta får en fiskalisk, granskande karaktär, och som genom sin begränsning till vissa objekt eller intresse- områden representerar en smal sektor i samhället.

Kulturvården måste ha vidare gränser. Den skall se bevarandet som en kontinuerlig vård av samhällsprodukterna med utsuddande av tidsgränser.

Därför är det otänkbart, att kulturvård skall vara begränsad till det ordagranna innehållet i speciallagar och förordningar. Detta för endast fram till att man ständigt kräver nya lagar och förordningar med mer preciserat innehåll och med strängare utformning för att uppnå sitt syfte.

Men detta är vad som i stor utsträckning sker. Man önskar komplettera fornminneslagen i olika hänseenden, man anser sig behöva en ny byggnadsminneslagstiftning, man vill ha utvidgade bestämmelser, när det gäller förbud mot export av kulturföremål osv, osv. Man kan gå igenom hela den antikvariska verksamheten och ständigt finna sådana yrkanden och önskemål.

Det är självfallet, att lagar och förordningar åldras genom den pågående utvecklingen och därför måste kompletteras och förnyas. Men i detta sammanhang är det inte det saken gäller.

Avsikten är i stället att först och främst peka på den stora betydelse de grundidéer har som utgör ursprunget till lagarnas utformning. Dessa idéer har i sin tur den allra största betydelse för lagarnas och förordningarnas tillämpning.

Vidare gäller det, att se dessa speciallagar i det större sammanhang, som de har med övriga bestämmelser och regleringar i dagens samhälle. Det är i ett sådant sammanhang, som de allmänna bestämmelser och hänvisningar rörande kulturvården, som man bland annat finner i bygglagstiftningen, är så betydelsefulla. 
Det är det samhällsmässiga sambandet som ger dem dess styrka. Först med ett sådant samband övergår en fristående antikvarisk verksamhet till en kulturvård i samhällsbildningen.

Här finns då många önskemål. Framför allt gäller det att uppnå en bättre anpassning till samhällets nuvarande förhållanden. Kulturvårdens syften och verksamhet måste kunna samordnas med naturvårdens, med aktuella saneringsfrågor, med modern byggnadslagstiftning, med exploatering, med kulturlandskapets omdaning.

Detta skulle innebära, att man förvärvade en permanent och respekterad plats i samhällsbildningen med en verksamhet, som innebar positiva insatser för samhället. Detta är något helt annat, än ett aldrig så ambitiöst arbete, som består i att man räddar ett större eller mindre antal kulturminnen från förstörelse.

Kulturvården måste därför godtaga dagens samhällsprodukter, då de är morgondagens kulturminnen. Detta innebär, att man måste vara orienterad om den nybildning, som sker. Denna kringsyn är ofrånkomlig i den stora strukturförvandling, som nu sker.

I denna process kan man därför inte nöja sig med att gå ut för att bevara vissa företeelser, utvalda lösryckta element i ett stort omdaningsskede. Man måste i stället ta ställning till själva nydaningsprocessen, deltaga i diskussionen om denna, medverka i utredningarna rörande nybildningen om man skall ha möjligheter att hävda bevarandet såsom innebärande vård och fortsatt brukande av värdefulla samhällsprodukter; produkter som skall fylla en väsentlig funktion i det moderna samhället.

I det omvandlingsskede, som man nu är inne $i$, är det dock inte ovanligt, att man går ut i krav på att bevara till exempel vissa byggnader, utan att man har deltagit på ett förberedande stadium i diskussionerna rörande nybildningen och orsakerna till denna. Går man denna väg, så blir resultatet ofta, att man kanske lyckas att bevara ett antal utvalda objekt, men helt fristående från nybildningen.

Framgången eller misslyckandet kommer då att vara beroende av hur stora summor samhället anser sig ha råd med att 'offra' för att rädda dessa kulturminnen på samma sätt, som när man köper en dyrbar tavla eller ett föremål till ett museum för att öka dess samlingar eller för att fylla en beklaglig lucka i beståndet.

På samma sätt för man vaga resonemang om kulturlandskapets förvandling. Man klagar över att det ljusa öppna åkerbrukslandskapet har försvunnit och blivit ersatt med ett mörkare skogslandskap utan att analysera orsakerna härtill.

Här har dock under många decennier skett en förändring inom åkerbruk och skogsbruk, och som givetvis sker ännu i dag, med många utredningar, politiska beslut och en teknisk och ekonomisk utveckling, som så småningom har fört fram till detta resultat.

En sådan utveckling, som man inte har varit med om att diskutera eller analysera, kan man nu inte bara inta en negativ inställning till. Den är en produkt av en samhällsutveckling med politiska, ekonomiska och sociala förutsättningar.

Det kulturlandskap, som vi i dag har, kan inte principiellt vara sämre än det tidigare. En sådan ståndpunkt har inget att göra med att man inom kulturvården strävar efter att bevara äldre landskap eller observerar och reagerar mot missförhållanden, som det moderna samhället för med sig.

Denna nödvändiga anknytning till sam- 
SVERKER JANSON

94 hällsbildning och nybildning gör, att kulturav arbetet till beslutsprocesserna i de samhällsvården inte kan låta nöja sig med att avlåta antikvariska yrkanden eller yttranden, vara remissinstans, falla tillbaka på speciallagar och förordningar eller komma med bevaringsplaner av olika slag i samhällets ytterområden, där det ekonomiska trycket inte är så starkt. politiska organen och där verka för sina syften.

Ur: Sverker Janson, Kulturvård och samhällsbildning (Nordiska Museets handlingar 83), Lund 1974, s. 42-47.

Man måste i stället flytta över en stor del 